\title{
religion .

\section{Politics as a Vocation: Prayer, Civic Engagement and the Gendered Re-enchantment of the City}

\author{
Amy Duffuor ${ }^{a}$ And Alana Harris ${ }^{a}$ *
}

\begin{abstract}
Drawing upon extensive oral history interviews and long scale participant observation in two London churches, an ethnically diverse Catholic parish in Canning Town and a predominantly West-African Pentecostal congregation in Peckham, this article compares and contrasts differing Christian expressions and understandings of 'civic engagement' and gendered articulations of lay social 'ministry' through prayer, religious praxis and local politics. Through community organizing and involvement in the third sector, but also through spiritual activities like the 'Catholic Prayer Ministry' and 'deliverance', Catholics and Pentecostals are shown to be re-mapping London - a city ripe for reverse mission through contesting 'secularist' and implicitly gendered distinctions between the public and private/domestic, and the spiritual and political. Greater scholarly appreciation of these subjective understandings of civic engagement and social activism is important for fully recognizing the agency of lay people, and particularly women often marginalized in church-based and institutional hierarchies, in articulating and actuating their call to Christian citizenship and the (re)sacralization of the city.
\end{abstract}

\section{Keywords}

Pentecostalism, Catholicism, laity, prayer, politics, London (UK)

\section{Author affiliation}

Amy Duffuor has a Master of Philosophy in Migration Studies from the University of Oxford. Her research interests concern faith-based civic engagement, urban space and

* Correspondence: Lincoln College, Turl Street, Oxford, OX1 3DR, England (UK).

E-mail: alana.harris@lincoln.ox.ac.uk.

a The authors would like to thank the editors and two anonymous peer reviewers for their helpful feedback and guidance. Thanks also to Mette Berg, Kwame Duffuor and Nesba Frimpong, Timothy Folkard, Jane Garnett and the parishioners and congregants of both churches who have been so generous and supportive of this research.

This work is licensed under a Creative Commons Attribution License (3.0)

Religion and Gender | ISSN: 1878-5417 | www.religionandgender.org | Igitur publishing 
migrant political activism. Amy has conducted ethnographic research on the African diaspora in the United Kingdom, United States and Ghana. Recent publications include 'Moving Up and Moving Out? The expansion of a London-based African Pentecostal Church' in David Goodhew (ed.), Church Growth in Britain, 1980 to the Present Day (Ashgate 2012, 145-160).

Dr. Alana Harris is the Darby Fellow in History at Lincoln College, University of Oxford. Her research interests span the history of religion, gender and migration/transnationalism. She has recently commenced a project exploring religious faith, space and diasporic communities in East London over the long-twentieth century under the auspices of the Oxford Leverhulme Diasporas Programme. Other publications include Faith in the Family: A Lived Religious History of English Catholicism, 1945-82 (MUP, 2013) and a co-edited volume (with Jane Garnett), Rescripting Religion in the City: Migration and Religious Identity in the Modern Metropolis (Ashgate 2013).

\title{
Introduction
}

Delivered as a lecture in Munich on January 28, 1919 in the wake of Germany's defeat in the First World War and the political instability that followed, the concluding riposte of Max Weber's famous essay 'Politics as a Vocation' asserted:

\begin{abstract}
Anyone who seeks the salvation of his soul and that of others does not seek it through politics, since politics faces quite different tasks, tasks that can only be accomplished with the use of force. The genius, or the demon, of politics lives in an inner tension with the God of love as well as within the Christian God as institutionalized in the Christian churches, and it is a tension that can erupt at any time into an insoluble conflict. ${ }^{1}$
\end{abstract}

Such a cynical assessment of the compatibility of an 'ethics of conviction' and 'responsibility' (found, for example, in the rare case of Martin Luther's 'vocation for politics') $)^{2}$ underpinned Weber's entire intellectual assessment of a rationalized, bureaucratized, 'disenchanted' capitalist modernity, epitomized by and experienced within the consumer city/metropolis. ${ }^{3}$

While Weber's sophisticated articulation of the 'secularization thesis' has proved a foundational tenet of modern sociology, recent scholarship now wrestles with the empirical presence of religion within the public arena and the everyday practices of many Western Europeans. The vitality and potency of faith convictions and religious activity have prompted social commentators to speak of our 'post-secular' condition and the 'return' of religion, ${ }^{4}$ while

\footnotetext{
1 M. Weber, 'Politics as a Vocation' in D. Owen and T.B. Strong (eds.), The Vocation Lectures, Indianapolis: Hackett Publishing Company 2004, 90.

2 Ibid., 92.

3 M. Weber, The City, New York: Free Press 1966.

4 J. Beaumont and C. Baker (eds.), Post-Secular Cities: Space, Theory and Practice, London: Continuum 2011; S.A. Munoz, 'Ethno-Faith-Burbs: Religious Affiliation and Residential Patterns of the Indian Ethnic Populations of Dundee and Glasgow' in Journal of Intercultural Studies 32:2 (2011), 115; F. Dodsworth, e. Vacchello and S. Watson, 'Shifting Religions and Cultures in London's East End' in Material Religion 9:1 (2013), 86-113.
} 
others analyze the ways in which religious actors and conviction politics were masked by secular, welfare state projects after the Second World War. ${ }^{5}$ Feminist perspectives have further augmented this scholarship, critiquing central tenets of the secularization thesis which have drawn sharp distinctions between religious orthodoxy and spirituality, and testing commonly-held interpretative assumptions about late-twentieth-century transformations in female piety in Britain - whether since the 1960s (in terms of individualization and heightened social autonomy) ${ }^{6}$ or since the 1980s (in the form of women's attraction to holistic spiritualities which have permitted a reframing and reorientation of traditional female roles). ${ }^{7}$ Through adopting an intersectional understanding of gender and religion (combined with other categories of analysis such as ethnicity, mobility and class), ${ }^{8}$ and through focusing on institutional and hierarchical religious organizations in which women carve out for themselves alternative constructions of female agency and authenticity, ${ }^{9}$ this article extends upon such feminist analysis - contributing to current discussions of the post-secular in eschewing historical definitions which under-estimate continuities across the 20 th- and 21 st centuries. ${ }^{10}$

5 J. Eade, "Excluding and Including the "Other" in the Global City: Religious Mission Among Muslim and Catholic Migrants in London' in N. Alsayyad and M. Messoumi (eds.), The Fundamentalist City: Religiosity and the Remaking of Urban Space, London: Routledge 2011, 283-302; A. Bäckström, G. Davie, N. Edgardh and P. Pettersson (eds.), Welfare and Religion in $21^{\text {st }}$ century Europe, Farnham: Ashgate 2010.

6 C. Brown, The Death of Christian Britain, 2nd ed., London: Routledge 2009 and Religion and the Demographic Revolution: Women and Secularisation in Canada, Ireland, UK and USA since the 1960s, London: Boydell and Brewer 2012; E. Sointu and L. Woodhead, 'Spirituality, Gender and Expressive Selfhood' in Journal for the Scientific Study of Religion 47:2 (2008), 259-276.

7 K. Aune, 'Much Less Religious, a Little More Spiritual: the Religious and Spiritual Views of Third-Wave Feminists in the U.K.' in Feminist Review 97 (2011), 32-55; K. Aune, S. Sharma and G. Vincett (eds.), Women and Religion in the West: Challenging Secularization, Aldershot: Ashgate 2008.

8 L. McCall, 'The Complexity of Intersectionality' in Signs 3 (2005), 1171-1180; P. Pessar and S. Mahler, 'Transnational Migration: Bringing Gender In' in International Migration Review 37:3 (2003), 812-846. Examples include E. Kofman, Gender and International Migration in Europe: Employment, Welfare and Politics, London: Routledge 2000; F. Anthias and G. Lazaridis (eds.), Gender and Migration in Southern Europe: Women on the Move, Oxford: Berg 2000; L. Thomas and A. Brah, 'Religion and Spirituality' in Feminist Review 97 (2011), 1-4.

9 Amy Hollywood, 'Gender, Agency and the Divine in Religious Historiography' in Journal of Religion 84:4 (2004), 514-528; J. de Vries, 'Rediscovering Christianity after the Postmodern Turn' in Feminist Studies 31:1 (2005), 135-55; S. Bracke, 'Conjugating the Modern/Religious, Conceptualizing Female Religious Agency: the Contours of a "PostSecular" Conjecture' in Theory, Culture and Society 25:6 (2008), 51-67 and J. Garnett and A. Harris, 'Wounding and Healing: Dealing with Difference in Christian Narratives of Migrant Women in East London since the 1980' in Women's History Review 22:4 (2013) (doi:10.1080/09612025.2013.769379).

$10 \mathrm{~J}$. Beckford, 'Public Religions and the Postsecular: Critical Reflections' in Journal for the Scientific Study of Religion 51:1 (2012), 1-19 and L. Kong, 'Global Shifts, Theoretical Shifts: Changing Geographies of Religion' in Progress in Human Geography 34:6 (2010), 755-776. 
Drawing upon over 150 oral history interviews and participant-observation over twelve months in two London churches, this article compares and contrasts differing Christian understandings and expressions of 'civic engagement' and the gendered articulation of 'social ministry' through prayer, praxis and local politics. This textured discursive analysis of the life narratives of ethnically diverse parishioners from a Catholic church in Canning Town and predominantly West-African congregants from a Pentecostal church in Peckham illustrates the efforts of these Christians, contra Weber, to 'save souls' through political activity (as broadly conceived) and, in doing so, to re-enchant London as a global city ripe for reverse mission. ${ }^{11}$ While Weber would not have recognized much of the activity described in this article as falling within his definition of 'politics', and those drawing upon the theories of Slavoj Žižek would speak instead of the post-political polis in characterizing (amongst other actors) the role of these faith communities, ${ }^{12}$ an influential strand of scholarship now looks to religious organizations as providing forms of civic social capital and practice..$^{13}$ In this vein, this article adopts a post-Weberian understanding of 'politics as a vocation'. Gender emerges as an important lens, coupled with attention to the urban dynamics of transnational migration, for this 're-mapping' breaks open Weberianinflected distinctions between the public and the private/domestic, between the spiritual and the political, and thereby highlights the roles played by lay women (and men) independent of clergy, mainstream political parties and differing institutional hierarchies in their call to Christian witness in the city. ${ }^{14}$ Following an introduction to the two church communities studied, it examines congruent (and contrasting) notions of prayer, local engagement and political activity across distinct denominational settings, and the ways in which gender is understood in its multiplicity of readings, including the interrelationships between masculinity and femininity, and inflections of family circumstances and generation.

\section{Catholics in Canning Town and Pentecostals in Peckham}

Whether described as the 'post-secular city', the 'fundamentalist city' or the 'diasporic city with ethnoburbs', there is an acknowledgment by many schol-

\footnotetext{
${ }^{11}$ R. Catto, 'Reverse Mission: From Global South to Mainline Churches' in D. Goodhew (ed.), Church Growth in Britain 1980 to the Present, Farnham: Ashgate 2011, 91-108.

12 E. Swyngedouw, 'The Zero-Ground of Politics: Musings on the Post-Political City' in New Geographies 1 (2009), 52-61.

${ }^{13}$ E.g. L. Bretherton, 'A Post-secular Politics? Inter-faith Relations as a Civic Practice' in Journal of the American Academy of Religion 79:2 (2011), 346-377; P. Cloke and J. Beaumont, 'Geographies of Postsecular Rapprochement in the City' in Progress in Human Geography (April 2012), 1-25 (doi: 10.1177/0309132512440208); A. Stepick, T. Rey and S.J. Maher (eds.), Churches and Charity in the Immigrant City: Religion, Immigration and Civic Engagement in Miami, New Brunswick (NJ): Rutgers University Press 2009; P. Levitt, 'Religion as a Path to Civic Engagement' in Ethnic and Racial Studies 31:4 (2008), 766-791. ${ }^{14}$ See J. Garnett and A. Harris (eds.), Re-scripting Religion in the City: Migration and Religious Identity in the Modern Metropolis, Farnham: Ashgate 2013.
}

Religion and Gender vol. 3, no. 1 (2013), pp. 22-41 
ars that religion now plays a prominent part in most Western European urban centres, including London, which is recognized as a 'super diverse' gateway city ${ }^{15}$ with heightened religious dynamism amongst migrant Christian and Muslim communities. ${ }^{16}$ Churches in London (and other 'global cities') are sites of Christian transnationalism and cosmopolitanism ${ }^{17}$ - spaces where people from diverse racial and ethnic backgrounds join together to celebrate the Eucharist, experience 'deliverance' and engage in activities beyond formal church services. Gender plays a particularly important role in these Churches, as women (and men) oscillate between simultaneously upholding and subverting traditional gender roles. The anonymized, particularized faith narratives that follow centre on a Catholic church in the Borough of Newham and an assembled Pentecostal community in the Borough of Southwark.

St. Margaret's Roman Catholic Church, Canning Town was founded in 1859 amidst the docks and industrial landscape of the East End and was initially sustained by many of the post-famine Irish Catholics (as well as other labourers and dockers from throughout the Empire and Europe). At the beginning of the twenty-first century, this late Victorian church (repaired following Blitz damage) now has a weekly attendance of around 1200 people from more than forty different migrant backgrounds, though congregation numbers and clerical confidence have fluctuated across the twentieth century. ${ }^{18}$ From the 1990s onwards, St. Margaret's church was in the charge of a single priest, most recently of a progressive theological leaning, but in 2008 the Bishop of Brentwood assigned the parish to a community of post-conciliar Swiss-reformed Dominican monks, with a more conservative liturgical agenda, and there is now wider pastoral support available to this very large parish community.

Contrasting with St. Margaret's Parish, FCl-Peckham is a recently established Pentecostal church ${ }^{19}$ within Universal Prayer Group Ministries (UPG), founded in 1985 by Rev. Dr. S.K. Boafo, a Ghanaian migrant to Britain. UPG has a history of expansion within and around London, as the first church started in North London and subsequently expanded to South London in 1998 under the name, Freedom Centre International (FCl-Peckham), which is co-pastored by Shadrach

\footnotetext{
15 S. Vertovec, New Complexities of Cohesion in Britain: Super-diversity, Transnationalism and Civil-Integration, London: CIC 2007.

${ }^{16}$ F. van Tubergen and J. Sindradottir, 'The Religiosity of Immigrants in Europe: a CrossNational Study' in Journal for the Scientific Study of Religion 50:2 (2011), 272-288; G. Smith, 'Ethnicity, Religious Belonging and Inter-faith Encounter: Some Survey Findings from East London' in Journal of Contemporary Religion 13:3 (1998), 333-351.

17 P. Levitt, God Needs no Passport: Immigrants and the Changing American Religious Landscape, New York: New Press 2007; N. Glick Schiller and A.S. Caglar (eds.), Locating Migration: Rescaling Cities and Migrants, Cornell: CUP 2011; M.A. Vasques and M.F. Marquardt, Globalizing the Sacred: Religion across the Americas, Chapel Hill: RUP 2003. ${ }_{18}$ M. Johnson and S. Foster, St Margaret's and All Saints Canning Town E16 1859-2009, Chelmsford: Brentwood Diocesan Press 2009.

19 See A. Adogame, 'Pentecostal and Charismatic Movements in a Global Perspective' in B. Turner (ed.) The New Blackwell Companion to the Sociology of Religion, Oxford: Blackwell 2010, 498-518; P. Gifford, African Christianity: Its Public Role, London: Hurst \& Co 1998; J.J. Robbins, 'The Globalization of Pentecostal and Charismatic Christianity' in Annual Review of Anthropology 33 (2004), 117-143.
} 
and Dorothy Ofosuware. Not coincidentally, this husband and wife team has close, familial links with the 'parent' church - Dorothy is the daughter of Dr. Boafo - and therefore the South London branch is literally part of an extended church family. Both Pastor Shadrach and Mama Dor (as Dorothy is affectionately known) are of Ghanaian descent and $\mathrm{FCl}$-Peckham has a primarily Ghanaian congregation (around 60\%), but also hosts congregants from Sub-Saharan Africa, Europe and the Caribbean. Worshippers are mainly first and second generation migrants with varying socio-economic backgrounds ${ }^{20}-$ and are overwhelmingly female while the church leadership is overarchingly male. The predominantly female congregant dynamic has been noted by other authors, ${ }^{21}$ and creates gendered articulations of liturgy and civic engagement amongst the laity. Specifically, women primarily participate in spiritual and private acts of civic engagement, whereas men predominantly engage in secular and public acts of civic engagement. $\mathrm{FCl}$-Peckham is an international church with six branches on two continents (UK and USA), serving over 800 members and expanded further through a new church plant (opened in February 2011) in the London suburb of Welling, Kent. This new church location is strikingly dissimilar from Peckham, as a predominantly white English, middle-class area compared to the inner-city ward of Peckham, where Black Africans comprise the largest ethnic minority. ${ }^{22}$

\section{The Power of Prayer}

Drawing upon the work of Swatos and Giordan, ${ }^{23}$ Nancy Ammerman ${ }^{24}$ and Meredith McGuire who focus on 'how religion and spirituality are practiced, experienced and expressed by ordinary people (rather than official spokespersons) in the context of their everyday lives', ${ }^{25}$ this article acknowledges the subjective convictions of Catholics and Pentecostals alike that personal prayer and devotional practices (such as speaking in tongues or the telling of rosary beads) are personally effective and vicariously efficacious. ${ }^{26}$ It also works from the premise that such 'private' and 'domestic' practices, outside formal institutional settings, are important foci for analysis (as they are implicitly gendered), and acknowledges the agency of laypeople historically, and particularly women, in appropri-

20 A. Duffuor, 'Moving Up and Moving Out? The Expansion of a London-based "African Pentecostal" Church' in D. Goodhew (ed.), Church Growth in Britain 1980 to the Present, Farnham: Ashgate 2011, 145-160.

21 See Aune, 'Much Less Religious', 32-55.

22 See http://www.southwark.gov.auk/downloads/download/308/population_and_ migration [Accessed 20 July 2010].

${ }^{23}$ W.H. Swatos and G. Giordan (eds.), Religion, Spirituality and Everyday Practice, Chicago: Springer 2011.

${ }^{24}$ N. Ammerman (ed.), Everyday Religion: Observing Modern Religious Lives, Oxford: OUP 2006.

${ }^{25}$ M. McGuire, Lived Religion: Faith and Practice in Everyday Life, Oxford: OUP 2008, 12.

${ }^{26}$ R. Orsi, 'Everyday Religion and the Contemporary World: The Un-Modern, or What was Supposed to Have Disappeared but Did Not' in S. Schielke and L. Debevec (eds.), An Anthropology of Everyday Religion, Oxford: Berghahn 2012, 145-161. 
ating and customizing religious traditions. ${ }^{27}$ Following the 'postsecular turn' in feminism, we assert that just as the personal is political, prayers and devotional forms which have collective aspirations need to be re-examined as, potentially, forms of civic practice with local but also sometimes diasporic, applications. Moreover, such a reappraisal allows for a better appreciation of women's agency, understood through their own subjective constructions, within religious institutions outside formal leadership positions. ${ }^{28}$

Catholic migrants in Newham have been active agents of the transformation of the British religious landscape through the reanimation (or re-introduction) of a variety of devotional activities that had waned for indigenous English Catholics in the post-war period..$^{29}$ The now internationally-renown Legion of Mary sodality (founded in Dublin in 1921 by the layman Frank Duff) is one such organization, which is structured around encouragement of mass attendance, visitation of the sick and 'the practice of the spiritual works of mercy' to marginalized people. While the local group of this confraternity was strong in Canning Town until after the Second World War, the Legion went into abeyance after the 1960s and was restarted in 1998, with a current active membership of sixteen. Legionnaires from St. Margaret's meet once a month to pray for mutual encouragement, and devote at least an hour each week to charitable activities such as hospital visitations, bringing Holy Communion to the housebound and to neighbourhood visitations. Bianca, who was born in Trinidad in 1944 and emigrated to Britain in the 1960s, was the Legion's first President and has performed this role for seven years, drawing inspiration from her mother's own involvement with the Legion in the Caribbean. She has an active prayer life centred on the rosary (she prays it with her husband every Sunday), which is supplemented through her religiously inspired activities for the Legion which have both a social and spiritual dimension. Contrasting 'over here' with her place of birth, Bianca describes her household visitations throughout ethnicallydiverse Plaistow as more introductory and sporadic. She sees them as nurturing community and a form of religious outreach, for 'people who are very glad for the visit' and who are 'alone in the house and will sit home and talk to you and offer you a cup of tea and biscuit'. Similar reflections are offered by another member Vincent, whose migratory story encompasses extended periods in Britain, then 'back home' in Nigeria, compelled by factors such as the civil war, educational opportunities for himself (and seven children) and healthcare. Vincent speaks of his involvement in the Legion since his return to Britain in 2000 as participation in an 'evangelizing society'. He narrates the aim of this Catholic 'prayer in action' group as the conversion of the 'luke-warm Catholic' or the non-Christian through 'door-to-door visitation without discrimination'. Vincent describes the mixed reception that his door knocking has received, from

27 S. Morgan and J. de Vries (eds.), Women, Gender and Religious Cultures in Britain, 1800-1940, London: Routledge 2010, 9 and T. Van Osselaer and T. Buerman, 'Feminization Thesis: A Survey of International Historiography and a Probing of the Belgian Grounds' in Revue d'Histoire Ecclèsiastique 103:2 (2008), 1-31.

${ }^{28}$ R. Braidotti, 'In Spite of the Times: The Postsecular Turn in Feminism' in Theory Culture and Society 25:6 (2008), 1-24; S. Mahmood, Politics of Piety: The Islamic Revival and the Feminist Subject, Princeton: PUP 2005.

${ }^{29}$ See A. Harris, Faith in the Family: A Lived Religious History of English Catholicism, 1945-82, Manchester: Manchester University Press 2013. 
closed doors and excuses about 'no time to talk' to occasional engaged conversations about Christianity, including with Muslims who 'have their point of view'. While a stalwart member of this society, Vincent becomes most animated when speaking about his membership of a newer pan-London, transnational group: the 'Catholic Prayer Ministry'. Founded in 1984 by Fr Edeh in Nigeria, the CPM members - who are 'mostly Nigerians supplemented by a few Indians' - perform set prayers daily and meet monthly in North-West London for all night devotion in front of the Blessed Sacrament. Centred upon the notion of intercessory prayers, the CPM dedicates its 24-hour monthly vigil to focused, personalized requests addressing illness and poverty, as well as universal prayers for social justice and world peace. For Bianca and Vincent, their prayers and religiously inspired activities outside a formal church setting are linked not only to personal spiritual sustenance but also a religiously inspired, empowering civic engagement, motivated by belief in the power of prayer to effect 'community cohesion' and societal transformation.

Similar to these Catholic parishioners in Canning Town, FCl-Peckham congregants believe that prayer is a spiritual act of civic engagement - fundamental for both individual and collective transformation. ${ }^{30}$ Prayer becomes particularly important in (mostly female) congregants' 'call' for political transformation in Peckham, as a result of the area's perceived high levels of crime, poverty, and undocumented migrant population. Church members regularly emphasize the role of prayer in civic engagement (praying, for example, over clothes and foodstuffs taken to local shelters) and assert that it too is a vital practice used to 'reach out' to the local community. However, it is important to note that the ways in which these congregation members pray differs from their Catholic counterparts, as animated bodily manifestations of prayer dominate FCl-Peckham's laity.

Given that Pentecostalism places a premium on the 'experience' of the worshipper, ${ }^{31} \mathrm{FCl}-$ Peckham congregants articulate their prayer life in a particularly visible, embodied way. FCl-Peckham congregants' Sunday prayers are not standardized and there is a certain degree of freedom within which the articulation and expression of prayer takes place - although there is a broadly consistent ritual arc to services, and a sense in which certain prayer practices conform to broadly recognizable forms. FCl-Peckham congregants are 'expected' to perform prayers in an individualized, customized way, as their ecclesiology centres upon individuals being 'touched' by the Holy Spirit, which manifests itself differently in different people. During a Sunday service, it is commonplace to see congregation members jumping up and down in their seats, walking around the main auditorium, speaking (and often yelling) in the divine language of tongues, ${ }^{32}$ and seeking and attaining 'deliverance'. Deliverance, specifically, is an intense and tangibly manifested experience - it is the process of 'saving'

\footnotetext{
${ }^{30}$ See C. Baker and H. Skinner, Faith in Action: The Dynamic Connection between Religious and Spiritual Capital, Manchester: William Temple Foundation 2006.

31 S. Coleman, 'Textuality and Embodiment among Charismatic Christians' in E. Arweck and P. Collins (eds.), Reading Religion in Text and Context, Hampshire: Ashgate 2006, 157-168; R. Marshall, 'Power in the Name of Jesus' in Review of African Political Economy 52 (1991), 21-37; G. Ter Haar, Halfway to Paradise: African Christians in Europe, Cardiff: Cardiff Academic Press 1998.

32 See S. Coleman, The Globalization of Charismatic Christianity, Cambridge: Cambridge University Press 2000.
} 
someone who is believed to be under demonic influences. At FCl-Peckham, this act involves a pastor, almost exclusively male, forcefully touching the head of a usually female congregant who typically falls to the ground convulsing, thereby signifying purification of the individual. This gendered dynamic is not only attributable to women's' congregational majority but as a result of the religiously bounded patriarchy that exists within $\mathrm{FCl}$-Peckham, and to a greater extent, across Pentecostalism. ${ }^{33}$ At $\mathrm{FCl}$-Peckham, the church leadership is predominantly male and the worshippers are predominantly female, which means that certain spiritual practices such as deliverance are clearly gendered - they promulgate a power dynamic whereby men 'perform' the acts of spiritual salvation and women 'receive' them. ${ }^{34}$

Nonetheless in some cases, women both 'perform' and 'receive' spiritual acts with social applications and specific appeal to women. A good example of this gendered practice of civic engagement is an activity of FCl-Peckham's women's ministry, Women of a Different Spirit. In the past, members organized prayer sessions for women having miscarriages, as Vivian (an executive committee member) explained:

There was one time when a lot of women were having miscarriages in the church. So we in the women's executive would pray in different locations in pairs around the clock to make sure that there are prayers all of the time for these women. And lo and behold, people got pregnant.

Women of a Different Spirit believe that bereavement is connected to 'pollution' of the body and demonic influences, ultimately constructing female congregants primary religious (and civic) identity as turning on their capacity to bear children. Given Pentecostalism's religiously-bounded patriarchy, it is vital for female Pentecostals to become 'mothers' - the embodiment and enactment of a traditional female role. Members of Women of a Different Spirit assert that their prayer is an act of feminism enabling female empowerment, challenging a secular feminist scholarship critiquing such religiously-inscribed and societally-prescribed gender roles. Women of a Different Spirit use prayers, which they believe heal members of the church or church-members' friends, and thus prayer becomes substantiated as a spiritual act by building strong and morally upright families in the community.

FCl-Peckham congregants perceive such prayers and deliverance to be a spiritual form of civic engagement, as the act of 'delivering' someone from evil benefits the wider society by creating good neighbours and model citizens. This 'model citizen' is characterized by being 'prosperous' and responsible in all aspects of life - having a job, family, house, car, good health, and being a lawful member of society - which will prompt others to change themselves and aspire to such grace and salvation. This might be thought of as the transitive property of civic engagement, for $\mathrm{FCl}-P$ eckham congregation members believe

33 See J. Robbins, 'The Globalization of Pentecostal and Charismatic Christianity' in Annual Review of Anthropology 33 (2004), 117-143; L. Woodhead, 'Gender Differences in Religious Practice and Significance' in J. Beckford and J. Demerath (eds.), The Sage Handbook of the Sociology of Religion, London: Sage 2007, 550-570.

${ }^{34}$ This subject is further discussed elsewhere in this special issue, see papers by Rey and also Silva and Rodrigues. 
that by bettering yourself and displaying that 'betterment' (especially as newlyarrived migrants) to the outside public, the church is engaged in a process of civic improvement, ensuring integration and 'social cohesion'. ${ }^{35}$ Church members often articulate this notion as 'leading by example' and 'seeing is believing for others.' This paradigm of civic engagement may be gently contrasted with St. Margaret's Church, for while Catholics also believe their prayers and examples can have tangible effects on the societies in which they live and those for whom they pray, there exists a stronger emphasis on the communal and ordered prayer collectives and greater male/female balance amongst the laity.

It is important to highlight that generally at FCl-Peckham, and indeed for Catholic women like Bianca and others who organize the large-scale Block Rosary (for family-related prayers and petitions) or the Union of Catholic Mothers (which functions for the many professional Nigerian female members as a kind of 'friendly society'), ${ }^{36}$ that these forms of prayer and spirituality are intimately connected to religiously-inflected and gendered understandings of social engagement and societal transformation. An exclusive focus on community leadership positions and political-party affiliation disregards subjective understandings of their vocation to societal transformation and the inauguration of the 'kingdom'. As will be explored subsequently, it is often male church leaders who are more involved in hierarchical, organized, public forms of civic engagement such as local council initiatives and political activism. Physical and spiritual acts of civic engagement are exalted in both churches, but institutionalized leadership in the Catholic and Pentecostal context is the preserve of men and it is these nominated, recognizable office bearers who receive accolades and acknowledgement from public actors co-opting the social capital of churches. As seen in these Peckham and Canning Town congregations, gendered lines demarcate but also complicate definitions of the physical and spiritual, and notions of the public and private spheres.

\section{Faith in Action: Religious Praxis and Local Politics}

Within a literature far more developed in an American context, authors like Foley and Hoge, ${ }^{37}$ Ebaugh and Chafetz, ${ }^{38}$ and Warner and Wittner ${ }^{39}$ have explored the ways in which congregations adapt to the changing needs of their ethnically diverse constituencies (encompassing differences of gender and class), develop strategies to strengthen their social networks, and acculturate members within local communities. FCl-Peckham's expansion to Welling, Greater London is a

\footnotetext{
${ }^{35}$ See N. Glick Schiller, '“There is no Power Except for God”: Locality, Global Christianity, and Immigrant Transnational Incorporation' in B. Turner and T. Kirsch (eds.), Permutations of Order, Farnham: Ashgate 2009, 133.

${ }^{36}$ A. Harris, 'Devoted East Enders: Catholicism in the East End of London' in D. Goodhew (ed.), Church Growth in Britain 1980 to the Present, Farnham: Ashgate 2011, 41-58.

37 M.W. Foley and D.R. Hoge, Religion and the New Immigrants: How Faith Communities Form our Newest Citizens, New York: OUP 2007.

${ }^{38}$ H.R. Ebaugh and J.S. Chafetz, Religion and the New Immigrants: Continuities and Adaptations in Immigrant Congregations, Oxford: AltaMira Press 2000.

39 R.S. Warner and J.G. Wittner (eds.), Gatherings in Diaspora: Religious Communities and the New Immigration, Philadelphia: Temple University Press 1998.
}

Religion and Gender vol. 3, no. 1 (2013), pp. 22-41 
prime example of the ways in which churches appropriate discourses that not only respond to the changing needs of their congregation, but also fulfil a calling to impact positively upon different communities. Thus, the grand opening of FCl-Welling was perceived to be an important act of civic engagement, as it allowed the church to fulfil its global mission by making the love of God, and the possibilities He enables, manifest to a wider community (Figure 1).

Daniel, a 30 year-old Ghanaian migrant who is a worship leader at the new church, happily exclaims, 'the whole set-up in Welling is God's promotion. ... I'm glad because it's the vision of the church and its come to pass. I'm glad because I am a part of what God is doing.'

However, Welling appears to be an unlikely choice for expansion, as it is a predominantly white middle-class, 'indigenous' English, ${ }^{40}$ and suburban area, which is a 40-minute train commute from Peckham. Pastor Shadrach, the head pastor, justifies his choice to the congregation with a prophecy, which reveals an $\mathrm{FCl}$ church with white and black people worshipping the same God. Pastor Kwabena, head of the music ministry at FCI-Peckham, recounts:

There is a prophecy in this church, that this church is a multicultural church. So if it is multicultural, then whites, blacks, Asians, indigos whatever culture will come into this house.

The reference to 'indigos' within Pastor Kwabena's explanation playfully underscores his vision of an $\mathrm{FCl}$ church that transcends racial categories (particularly of black and white), which are sketched as discursive and constructed rather than biologically essentialized. If distinctions of race, class and culture are to be exposed as irrelevant, Welling is seen to represent precisely the type of area that will enable $\mathrm{FCl}$-Peckham to fulfil its self-perception and aspirations. Therefore, it is important to realize that Welling's demographics and its history of race relations make it an especially desirable place for FCI-Peckham to expand.

In 1989, Welling became the national headquarters for the British National Party (BNP), which is a radical-right political party known for its racist, fascist and homophobic rhetoric and activities. According to Youth Against Racism in Europe, ${ }^{41}$ the presence of the party in Welling has historically sparked a rise in racist attacks in the area and three young black and minority ethnic men (Rolan Adams, Stephen Lawrence and Rohit Duggal) were murdered in racebased attacks between February 1991 and April 1993. Consequently, Welling became the site of numerous protests against the BNP regarding their use of violence and their divisive campaign platforms $\mathrm{s}^{42}$ and in 1995, the Welling Council shut down the BNP headquarters in an attempt to reduce its influence in the area. Over ten years later, Pastor Shadrach has encountered resistance from BNP members during $\mathrm{FCl}$ 's acquisition of the Welling property in 2009, prompting

40 Office for National Statistics, Census, 2001, accessed 18 February 2011, http://www. neighbourhood.statistics.gov.uk/dissemination/LeadDatasetList.do $? a=7 \& b=6173582 \& c=$ Falconwood + and + Welling $\& d=14 \& g=327257 \& i=1001 \times 1003 \& m=0 \& r=1 \& s=130472790732$ 8 \&enc $=1$ \&domainld $=16$.

${ }^{41}$ See http://www.yre.org.uk/towerhamlets.html [Accessed 8 March 2011].

42 D.K. Renton, 2005. Memories from Welling [Online], accessed 8 March 2011, http://www. dkrenton.co.uk/welling.html. 


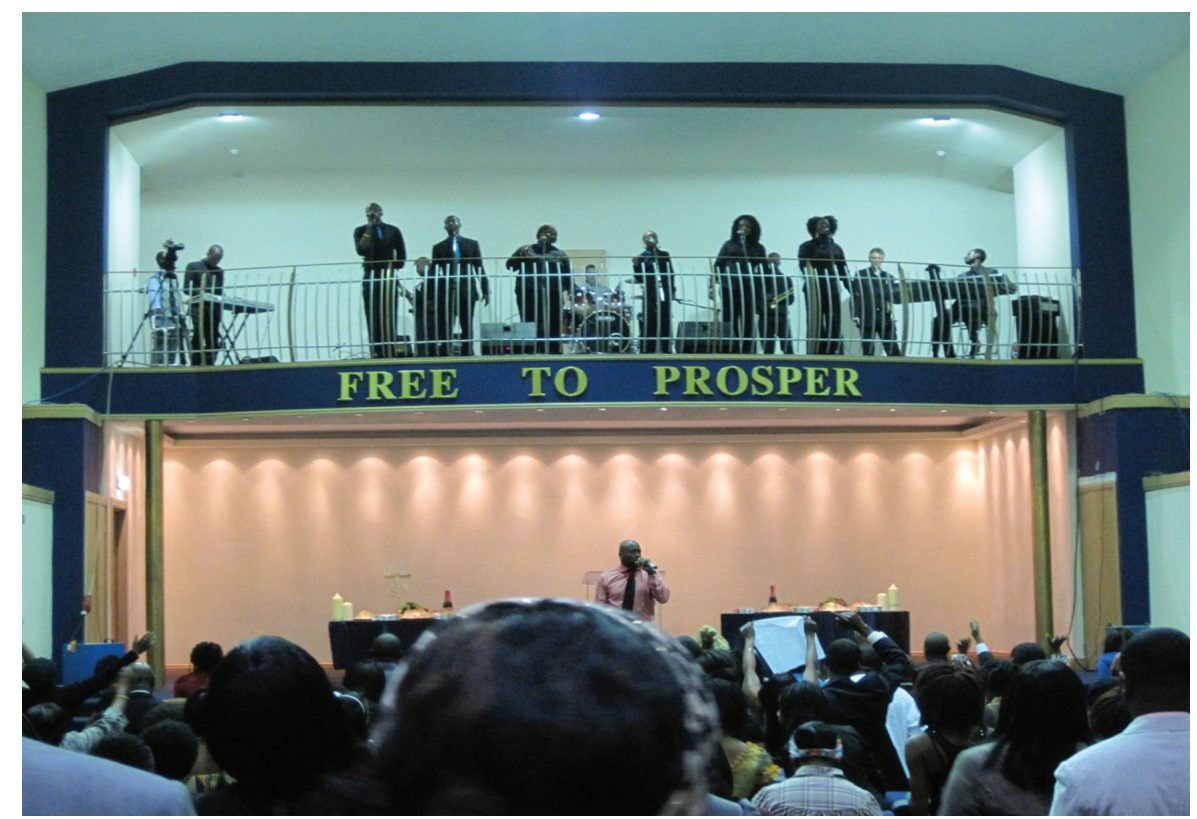

Figure 1: The grand opening of FCl-Welling, the main auditorium, 6th February 2011. Source: Authors' photograph.

him to articulate the utility of $\mathrm{FCl}$ 's presence here in terms of peaceful integration and religious pluralism for 'we have discovered that $\mathrm{FCl}$ can be effective regarding social cohesiveness in Welling .... they are beginning to realize that we are not bringing any trouble for them and we want to engage with them.'

$\mathrm{FCl}$ 's desire to attract Welling locals, who are predominantly white and some of whom have a historic distrust of minorities, underscores FCl's 'reverse mission' and their objective of portraying themselves as a visibly international church. The reverse mission discourse posits that African pastors seek to attract European 'natives' to their churches in order to save and (re)convert them ${ }^{43}$ and Europeans are perceived to need saving as a result of their penchant for homosexual practises, drug use, pre-marital sex, and other ills associated with modernity and modern inner-city lifestyles. Although the term is problematic due to its normative assumptions of a standard path of mission that can be reversed ${ }^{44}$ the idea does encapsulate part of FCl-Peckham's self-understanding. For example, Pastor Elijah, a middle-aged Ghanaian migrant in charge of setting up new FCl branches, asserts his eagerness to mission to Welling's 'indigenous':

I am excited about the Welling project because we are fulfilling the calling of the ministry. The main calling is to expand and affect different communities. ... The people in Welling are going to be affected by the gospel of Christ. ...It's about

${ }^{43}$ D. Koning, 'Place, Space and Authority: The Mission and Reversed Mission of the Ghanaian Seventh-day Adventist Church in Amsterdam' in African Diaspora 2:2 (2009), 203-226.

44 Ibid., 203. 
going to Welling and really affecting the natives. For the natives, we are making every effort to reach out to them and see how best integration can work out.

Pastor Elijah's rhetoric of civilising colonization and integration signifies the appropriation of a new position for African Christians, who are usually situated at the receiving end of the global power geometry. ${ }^{45}$ It also touches on a broader community cohesion agenda, which is reflective of contemporary British political discourse. ${ }^{46}$ Ultimately, $\mathrm{FCl}$-Peckham propagates a reverse mission rhetoric encompassing 'faith', 'community', and 'impact', which reflexively interpolates different narratives, identities and gender roles within that dialogue. ${ }^{47}$

It is noteworthy that this paradigm of spiritual and social engagement has been adapted to Welling as a distinct place and with gendered action plans. This is evident in a flyer for the church opening, which described the event as 'The Grand Opening of FCI Welling Church and Community Facility on February 6, 2011.' Val Clark, the local mayor, and Professor Kwaku Danso-Boafo, the Ghana High Commissioner to the United Kingdom, attended the commencement. The presence of these two politicians signified the simultaneously local and transnational dimensions of the church consecration, particularly the way in which FCl-Peckham's congregational identity is still rooted in a sense of 'home,' which is Ghana for most of the congregation. It is significant that the flyer accentuated both the 'church' and the 'community facility', as $\mathrm{FCl}-$ Welling clearly seeks to present itself as a religious and public space for the surrounding area. Pastor Shadrach describes the new church as a 'multipurpose healing centre' for everyone, explaining 'I want $\mathrm{FCl}$-Welling to have a GP, youth community centre, and legal centre. I want to make FCl-Welling a one-stop shop!' Similarly, Mama Dor intends to develop the Women of a Different Spirit group from Peckham beyond its existing prayer and leisurebased focus to offer here a women's health drop-in service, utilizing trained volunteers to address issues such as sexual health and blood pressure, and thus engage a cross-section of females within this wealthier, white locality. Medical and legal service provision has a proven cross-community application - FCl-Peckham congregants tend to conjoin prayer with practical solutions to health and immigration problems while increased, broader 'service provision' will have a fairly uncontroversial appeal in this host neighbourhood. These shifts in self-presentation and the articulation of its mission are seen as important for attracting potential Welling converts, who may draw sharper distinctions between religious and social welfare, and spiritual and social capital. It is evident that $\mathrm{FCl}$ has mobilized a conscious evangelistic strategy, adapting its former $\mathrm{FCl}-\mathrm{Peckham}$ practises and gendered civic engagement to the Welling demographic.

${ }^{45}$ K. Krause, 'Cosmopolitan Charismatics? Transnational Ways of Belonging and Cosmopolitan Moments in the Religious Practice of New Mission Churches' in Ethnic \& Racial Studies 34:3 (2011), 423.

${ }^{46}$ See M. Keith, 'Discovering Faith? The Hidden Contours of Political Participation and Devotional Practice in Contemporary East London' in J. Garnett and A. Harris (eds.), Rescripting Religion, 207-222.

47 See C. Rhodes and A.D Brown, 'Narrative, Organizations and Research' in International Journal of Management Reviews 7:3 (2005), 167-188. 
In order to publicize these initiatives to the Welling community, $\mathrm{FCl}$ has created networks with local authority figures to build social capital, which is part of their paradigm and practice of civic engagement. Pastor Kwabena reveals:

It all boils down to the relationships, you know? At the moment we have relationships with the police, with the councillors, we've already been doing the underground work and getting ourselves involved.

It is important to note that the congregation members who build these public networks are almost exclusively male, which reinforces a gendered dynamic whereby men participate in secular and high profile acts of civic engagement. Nevertheless, within these areas there are opportunities for female involvement, especially when related to children and young people who are seen as properly part of a 'female public and maternal domain'. ${ }^{48}$ For example Irene, the youth leader of $\mathrm{FCl}$-Peckham and FCl-Welling, discusses the new scope of youth activities and she postulates different ways for Regeneration Youth to effect change, given the area's history:

I don't know how people in Welling are going to react to the fact that they have a lot of black people coming. Racism is still alive, especially in the UK. ... It's going to be a bit of a challenge. ... We are going to hand out free cakes and say "come to our youth ministry" and go to the shops and ask people to hand out stuff.

Irene's eagerness to go on the streets of Welling and not Peckham is surprizing, given that both areas have a history of violent crime. What differentiates the two is Welling's higher socio-economic class demographic, which perhaps plays a role in Irene's ease at engaging the Welling community and manifesting domesticity on a 'street level', in contrast to the Peckham community. Thus, classed and gendered narratives are apparent in Irene's plans for outreach in Welling - this clearly intersects with 'appropriate' gender concerns, as the majority of Regeneration Youth members are females and notions of 'safety' and 'security' are areas of female influence and responsibility appropriately manifested within the public gaze.

When such youth initiatives require a more institutional interface, such as engaging with the Department for Communities and Local Government in the rehabilitation of young offenders, it is Pastor Yaw who works as a volunteer chaplain under the auspices of PECAN (Peckham Evangelical Churches Action Network). Representing FCl Peckham within this organization founded in 1989 to alleviate deprivation in Southwark (including a food bank, employment preparation, mental health support and employment training), Pastor Yaw described his role as mentoring 'youth and young offenders. When young people get released from prison they come to me and I give them the values that they need to live a Christian life'. As discussed in the section above on prayer, in Pastor Yaw's estimation it is spiritual transformation that will lead to successful rehabilitation and these ex-offenders' reclamation of a place in society as good citizens.

This conversionary mission or conviction politics, expressed through a public rhetoric of local political influence and the cultivation of sympathetic

${ }^{48}$ On maternal, 'domestic' rhetoric mobilized for political purposes, see M. Fumanti, '"A Light-Hearted Bunch of Ladies": Gendered Power and Irreverent Piety in the Ghanaian Methodist Diaspora' in Africa 80:2 (2011), 200-223.

Religion and Gender vol. 3, no. 1 (2013), pp. 22-41 
political actors, has been well honed by $\mathrm{FCl}$ 's presence in Peckham for well over a decade. While a handful of congregants have involved themselves in 'direct action' initiatives, such as safe streets campaigns, overwhelmingly it is those in church leadership positions who sit on the boards of various committees - those men who, as Weber would have it, have a 'genius' for the rough and tumble of secular politics. Underpinning this (male) strategy for privileging co-operation with established (and secular) official bodies like Southwark Council is the validation which involvement offers, but also a pragmatic estimation of the greater control provided by direct access. As Matthew, the Ghanaian project manager of the church, explains:

$\mathrm{FCl}$ targets bigger, more institutionalized organizations like Southwark Council because the small ones aren't organized and to get to them, we have to go through umbrella organizations. Southwark Council is the safest way for the church to operate and be partnered with other credible organizations like FCl.

This is an understanding of political engagement that is profoundly hierarchical and gender normative, as it was overwhelmingly the (male) leadership team who were chosen for representative positions on Peckham's Regeneration Town Planning Central Committee and who have cultivated personal influence with local MPs and Councillors. Only one male non-church leader participated in the aforementioned activities, which again emphasizes the hierarchical entrenchment within FCl's civic engagement. However, a more ambitious and 'democratized' form of practical civic engagement may be found when moving beyond local politics to examine the transnational and diasporic. Given that Ghana is the country of origin for most $\mathrm{FCl}$ members, the church (through members' tithes) is in the process of building a university in Ghana, and also wants to build a women's health centre, a job centre, and an orphanage in West Africa. Through their giving, and an invested role in priority setting and planning, female as well as male $\mathrm{FCl}$ members move beyond the parochial to embrace tangible civic activism in both England and Africa. ${ }^{49}$

As an echo of FCl's stated aspiration to transcend 'white, black, Asian, indigo' - which is, of course, sometimes undercut by its almost exclusively West-African infrastructure - St. Margaret's also sees itself as a 'global' church, building consensus at a community level but using quite different political (and spiritual) strategies. Paralleling Pastor Yaw's mentoring of young offenders for PECAN, but given status (and remuneration) as a professional employee within a charitable organization, Kate works for Anchor House. Created in 1969 by the Catholic Church in Canning Town (next to St. Margaret's church) to provide temporary accommodation to out-of-work seafarers, this service has transformed itself following the closure of the docks to provide a residential centre for the homeless and programmes to build confidence and life skills. Kate, who was born in Forest Gate to a Jamaican mother and an American GI father, grew up in the West Indies and America (where she was exposed to Jewish and Catholic religious practices), and now combines the Jehovah's Witness commitment of her husband with a flexible Catholic faith. Speaking of her work with many of the $200+$ residents each year at Anchor House, Kate describes her job

${ }^{49}$ P. Levitt and N. Glick Schiller, 'Conceptualizing Simultaneity: A Transnational Social Field Perspective on Society' in International Migration Review 38:3 (2004), 1002-1039. 
as testing her boundaries, specifically of Christian charity but also aiding and motivating people from all walks of life, races and religions by 'talking about and through difference'. As a place that's 'not religion-specific' and has 'loads of Muslims' (both staff and residents), she recounts everyday and non-precious inter-religious interaction: 'all tend to get on, there is this banter ... and the talk isn't just about football. Everybody comes down to watch the football on the telly. They all have their go at each other's religions. And as well, there's Indian Muslims, Somali Muslims, Eritrean ... Muslims from all different parts of the world'. Alongside providing residential support, employment and benefit advice, Kate reflects on her role as a woman in helping the predominantly male clientele recognize symptoms of depression and come to terms with what they characteristically think of as a woman's illness and emasculating frailty. When speaking about a client who said he thought he had metaphorically 'gone into this cupboard and locked myself in, and it's just so dark', her response to him was:

"Well, we won't try to PULL you out of the cupboard, what we'll try to do is to drill some holes through the door, so we can let a bit of daylight in". And we work from that. And I think it's helping ... he's slowly getting out of himself.

In this narrative of light entering dark, entombing places, Kate replays a quintessentially Christian hope in the transformative possibilities available to everyone and which she feels personally called upon to facilitate. Kate's third-sector employment (which she conceives of as a form of lay ministry) shares some characteristics with Pastor Shadrach and Mama Dor's aspirations for volunteers at $\mathrm{FCl}$ Welling - she provides a profoundly important public service (encompassing mental health, jobs retraining and welfare dependency) that is animated by personal conviction and a religious commitment. In this example of 'faith in action', the spiritual may seem secondary or indeed subordinated to social work, but in fact it explains Kate's motivation to ameliorate poverty, ill health and addiction and to empower people to escape homelessness, mental illness and crime. Nevertheless, there are also profound differences which contrast between, broadly speaking, a Pentecostal 'prosperity gospel' and the enactment that 'Catholic social teaching' elicits. The FCl Peckham and Welling initiatives are practical, targeted and adaptive but they build upon clearly demarcated notions of individualized welfare, domesticated gender differences and the privileging of (male) clerical leadership within the public arena. Of course the Catholic Church too retains its male clergy who exercise authority and sometimes re-inscribe patriarchal gender roles, but because of the scale and spread of the denomination, and an acute shortage of priests, the Catholic Church has been forced to open up opportunities for employment to women like Kate within its organizational structures. Unlike Irene or Mama Dor, Kate has independence and professional agency beyond areas that $\mathrm{FCl}$ might designate as 'women's concerns', helping and up-skilling vulnerable men in a caring capacity that does not emanate from an extended notion of domesticity or maternity. Moreover, in contrast to FCl's self-affirming and empowering ascription of a 'reverse mission', Kate's aspirations do not encompass 'conversion' or the collapse of ethnic or religious boundaries. She speaks instead of communicating across 'difference' and negotiating shared strategies for personal and societal improvement through the identification of common ground. There is a confidence, which others may see as complaisance, in this non-evangeliz-

Religion and Gender vol. 3, no. 1 (2013), pp. 22-41 
ing strategy of acknowledging different value systems and seeking a crosscommunity application. Yet despite these theological variations, and different ecclesiological strategies, in outcomes there may be very little difference between Kate's community building in Canning Town and the adaptive Pentecostal strategies proposed for Kent.

Pastor Kwabena's recognition that effective civic activism 'all boils down to the relationships' is a conviction that is shared by Father John, who was born in Canning Town in 1955 and who many decades later returned as priest of St. Margaret's parish. Raised on tales of Keir Hardie (West Ham MP and one of the founders of the Labour Party) soliciting Catholic votes through endorsement from the St. Margaret's pulpit, a more communitarian politics underpinned his parish's agreement in 1996 to become a founding member of The East London Communities Organization (TELCO). Based on the Chicago-model of community organizing inaugurated by Saul Alinsky, ${ }^{50}$ this now powerful and prominent organization under the umbrella of London Citizens is a diverse alliance of over 90 civil society institutions, predominantly from the faith sector, but including labour, educational and community-based organizations. Its activities, which identify consensual action-based initiatives without explicit ideological articulations, have included campaigns spanning the London 2012 Olympics legacy, the fight for a Living Wage, ${ }^{51}$ and protection for migrants and asylum seekers in line with the refugee and immigration-based initiatives of many religious organizations in North America. ${ }^{52}$ When asked about their involvement in the parish-based activities that feed into these broader campaigns, Cockney-born husband and wife team, Margaret and John enthuse about parishioners' attendance at rallies for affordable housing and the success of the national living wage campaign which exposed (through canny use of the media) the disparity between the wages of those employed in the Canary Wharf buildings (both bankers and cleaning staff). Nigel, who was born in Nigeria and who migrated to London eighteen years ago when in his early twenties, highlights instead the 'simple and gentle change' possible to address foul-smelling emissions from a factory in Canning Town 'not through violence, but by standing and saying "you can't live here and smell that" ' and through TELCO we can 'just make things happen'. Other small scale, local issues such as lighting around train stations, and the worrying rise of knife crime amongst youth have also been tackled. For Belinda, a Filipino woman who came to Canning Town in 1986 (after sojourns in Nigeria and California), her founding membership of TELCO was motivated by an appreciation of community-based organizing as building cohesion within a church as well as beyond in the community, for 'it gets people together and gets people talking' (and indeed singing - see Figure 2).

For many of the other women involved, the focus on neighbourhood amenities and safety and the gendered-dimensions of poverty and marginality

\footnotetext{
50 S. Alinsky, Rules for Radicals, New York: Vintage Books 1972.

51 J. Willis et al., 'Religion at Work: the Role of Faith-Based Organisations in Living Wage Campaigns for Immigrant Workers in London' in Cambridge Journal of Regions, Economy and Society 2:3 (2009), 443-61.

52 P. Hondagneu-Sotelo, God's Heart has no Borders: How Religious Activities are Working for Immigrant Rights, Berkley: University of California Press 2008.
} 


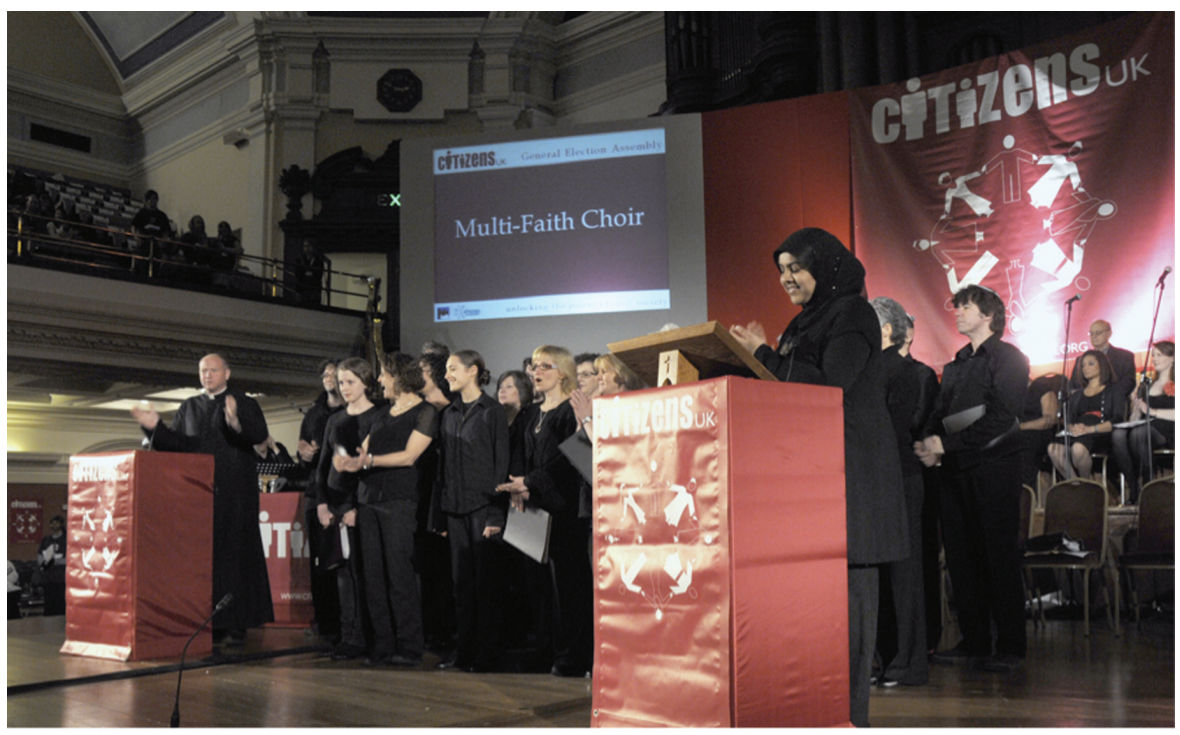

Figure 2: London Citizens multi-faith choir at a UK Election leaders rally in Methodist Central Hall, Westminster, 3rd May, 2010 (with Father John co-presiding). Source: Julio Etchart with permission from Demotix.

(through low-paid casual wages and lack of familial stability through irregular migrant status) chimed with key concerns. This is not a world away from the concerns of FCl's Women of a Different Spirit and Regeneration Youth, although TELCO rightly congratulates itself on a more grass roots, democratic form of involvement (for men and women) through its 'listening campaigns', annual (semi-liturgical) assemblies, publicly-raising 'stunts' and membershipbased activities. Nevertheless, in the higher reaches of its cross-party, consensus-building influence upon political actors and policy makers, it does rely on paid, trained 'community organizers' (many of whom are young males seeking an alternative to local party politics) and on key power brokers (most of whom are Catholic and Anglican clergy or trade union officials). When viewed through this broader organizational lens, the greater opportunities for gender-neutral, egalitarian political agency and activism offered through TELCO are slightly undercut. Moreover, when considered in this light - as a contrast to the direct (right wing and sectarian) politics of the Christian People's Alliance in Newham ${ }^{53}$ or the influence of religious organizations in the Labour Party in nearby Tower Hamlets - both our Catholic and Pentecostal churches preferred a light-touch, organic and informal outlet for civic concern and political activism to the 'force', as Weber puts it, of institutional party politics. As Catholic layman Nigel surmised, this is a striving for 'simple and gentle change' endorsed 'by God', which works 'gradually' but can evolve to embrace larger issues and a wider constituency.

${ }^{53}$ G. Smith, 'Faith in Local Government: The Emergence of Religion in the Politics of an Inner London Borough, 1975-2006' in Politics and Religion Journal 4:2 (2010), 157-82; S. Dhaliwal, The Growth of Religion in the Public Sphere in Two London Boroughs: Ealing and Newham, PhD thesis 2012, Goldsmiths.

Religion and Gender vol. 3, no. 1 (2013), pp. 22-41 


\title{
Conclusion
}

Towards the conclusion of his lecture on 'Politics as a Vocation', Weber returned to his longstanding preoccupation with the role of religion in public life, musing:

\begin{abstract}
The great virtuosos of unworldly goodness and the love of humankind, whether from Nazareth or Assisi or the royal palaces of India, have never operated with the methods of politics, that is, the use of force. Their kingdom was 'not of this world', and yet they were and are at work in this world, and the figures of Planton Karatayev and Dostoyevsky's saints still remain their nearest successors ... In this sense an ethics of conviction and an ethics of responsibility are not an absolute antithesis but are mutually complementary, and only when taken together do they constitute the authentic human being who is capable of having a 'vocation for politics'. ${ }^{54}$
\end{abstract}

Momentarily suspending the sharp dichotomies of a disenchanted, secularized modernity in the exceptional case of saintly individuals, a strict Weberian analysis would descry our designation throughout this article of prayer and religiously-inspired praxis as a form of politics available to Christian men and women within two contrasting denominational settings. However, this is to disregard the ways in which these Catholic and Pentecostal believers subjectively understand their spiritual and social activities - for them, belief without benevolence is inexplicable, and there is no real distinction between religious and social welfare, personal service and public spiritedness. Eschewing the ahistorical, teleological logic of the secularization thesis, ${ }^{55}$ we have fore grounded the activities of the laity, and particularly of non-ordained women, who pray for and minister to their fellow congregants, neighbours and communities outside of clerical or formal leadership positions. This approach also builds on feminist discourse and current discussions of the post-secular, by privileging the contextual, lived experiences of male and female congregants and thereby highlighting continuities across the 20th- and 21st centuries. Such an approach also has the advantage of emphasizing the continuum between 19th century notions of philanthropy, altruism and public service, vested in Christianity, which some scholars have argued were displaced by the Welfare State in the 20th century ${ }^{56}$ but more recent scholarship is subtlety contesting. ${ }^{57}$ Within the inner city boroughs of Newham and Southwark and increasingly in the suburbs (like Welling) too, ${ }^{58}$ Christians of different theological and denominational backgrounds are

\footnotetext{
${ }^{54}$ Weber, 'Science as a Vocation' in Owen and Strong (eds.), The Vocation Lectures. Indianapolis: Hackett Publishing Company 2004, 90, 92.

55 See L. Woodhead and R. Catto (eds.), Religion and Change in Modern Britain, London: Routledge, 2012; cf. S. Bruce, Secularization: In Defence of an Unfashionable Theory, Oxford: OUP 2011.

${ }^{56}$ F. Prochaska, Christianity and Social Service in Modern Britain: The Disinherited Spirit, Oxford: OUP 2006.

57 Mathew Hilton and James McKay (eds.), The Ages of Voluntarism: How We Got to the Big Society, Oxford: OUP 2011.

${ }^{58}$ C. Dwyer, D. Gilbert and B. Shah, 'Faith and Suburbia: Secularisation, Modernity and the Changing Geographies of Religion in London's Suburbs' in Transactions of the Institute of British Geographers (2012), 1-17 (DOI: 10.1111/j.1475-5661.2012.00521.x).
} 
reclaiming and reanimating an ethic of self-help, civic service and communitarian politics, which they see as part of the logic of their religious convictions and social responsibilities. While only aspirationally embodying the 'saintliness' that Weber makes a precondition, many of the men and women we have interviewed feel vocationally-committed, if not compelled to a life of prayer and religiously-inspired altruism and activism. Moreover, they harmonize these activities with gendered understandings of their familial, social and ethnic identities in complex and sometimes counter-intuitive ways - reflected in the case studies employed in this article. 